\title{
Membaca Islam dalam Diversitas Sejarah Peradaban
}

DOI 10.18196/AIIJIS.2016. 0059.139-143

\section{MUHAMMAD AZHAR}

Program Doktor UMY.

$\begin{array}{ll}\text { Judul } & : \text { Keragaman dan Perbedaan: Budaya dan Agama dalam Lintas } \\ & \text { Sejarah Manusia } \\ \text { Penulis } & : \text { Almakin } \\ \text { Penerbit } & \text { : UIN Suka-Press } \\ \text { Kota } & : \text { Yogyakarta } \\ \text { Tahun } & : 2016 \\ \text { Halaman } & : 288 \\ \text { ISBN } & : 9786021326480\end{array}$

Buku yang ditulis al-Makin, dosen UIN Yogya, jebolan Universitas Heidelberg, Jerman (2008) ini, menarik untuk dibaca, dikaji bahkan dikembangkan menjadi riset lanjutan, baik bagi sang Penulis sendiri maupun bagi yang membacanya. Secara kontekstual, karya ini amat relevan dengan munculnya berbagai dinamika sosial politik, budaya hingga agama akhir-akhir ini. Hadirnya buku ini bagaikan oase bagi mayoritas masyarakat yang haus dengan indahnya perdamaian di tengah pluralitas sosial yang ada. Sejauh ini, Penulis berasumsi bahwa realitas masyarakat Indonesia - bahkan dunia - yang palural ini belum banyak diperkaya dengan dukungan kajian teoritik keilmuan tentang pentingnya memahami fenomena perbedaan masyarakat, baik secara ontologis maupun epistemologis (dengan berbagai variannya).

Mungkin itu sebabnya, pluralitas sosial seringkali melahirkan kebingungan bagi banyak komponen masyarakat dan cenderung berdampak pada munculnya konflik-konflik sosial, politik, budaya hingga agama. Fenomena konflik justeru melahirkan masyarakat yang hopeless, penuh "kutukan" - yang seringkali disertasi dengan teriakan kalimat-kalimat religius, dan sejenisnya tanpa memiliki khazanah yang memadai untuk memberikan solusi. Bukankah hidup akan selalu menghadapi banyak masalah yang membutuhkan banyak 
solusi?. Seperti kata pepatah: "Daripada mengutuk kegelapan, jauh lebih baik menyalakan lilin". Relevansi buku ini adalah sebagai salahsatu upaya "menyalakan lilin" tersebut di tengah kegelapan atau kepengapan sosial budaya akhir-akhir ini, tidak hanya untuk konteks Indonesia bahkan untuk seluruh penjuru dunia yang sarat dengan berbagai konflik.

Dalam buku ini, al-Makin, sebagai intelektual muda di tanah air, menguraikan secara luas - walau tidak semuanya secara mendalam - tentang lintas perjalanan umat manusia, dari aspek budaya dan agama. Inti dari topik buku ini adalah tentang keragaman yang sangat sesuai dengan fakta pluralitas bangsa Indonesia sejak awal berdiri hingga kini, yang sudah bersentuhan secara lebih massif dengan dunia global yang sarat dengan berbagai muatan "materi" konflik.

Dari segi metodologis, penulisan buku ini menggunakan pendekatan sejarah dan juga filsafat (tepatnya: filosofis). Yakni sejarah dan filosofi yang mencakup tentang konsepsi penciptaan dunia, penciptaan manusia dengan beberapa pandangan mitologis di dalamnya, persepsi tentang dunia itu sendiri, keragaman teologi dan God in history (h.11-141); lima kota metropolitan yang populer di era klasik (Damaskus-Suriah, Baghdad-Irak, Persia-Iran, Syriak dan Yunani-Eropa (h. 143-173). Pada bab enam, buku ini berisi tentang tradisi Beriman dan Berfikir hingga soal sistem kenegaraan (h.175-210). Lalu diakhiri dengan khazanah keagamaan Nusantara, diantaranya terkait dengan Hinduisme, Buddhisme, Kaliyuga dan Sinkretisme (h. 211-248).

Aspek keragamaan dikenal dengan istilah Pluralisme. Dalam kaitan dengan ini dikenal istilah: Pluralisme agama, Pluralisme filosofis dan Pluralisme sosiologis. Terkait dengan Pluralisme agama, dimana agama mencakup wilayah yang subjektif dan juga objektif. Wilayah subjektif jika diperdebatkan memang bisa menimbulkan konflik sebab menyangkut martabat internal masing-masing umat beragama. Untuk pluralisme yang subjektif keagamaan menyiratkan bahwa masing-masing umat beragama memiliki rasa - 'irfani-keagamaan yang subjektif secara internal, seperti tentang: metafisika atau ontologi keyakinan, serta perspesi tentang Tuhan (Tuhan yang Esa bagi muslim atau Tuhan Yesus bagi kaum Kristiani); juga tatacara ritualitas (sistem shalat bagi muslim maupun upacara Natalan).

Adapun pluralisme filosofis bisa lebih mendekati hal yang objektif yakni terkait "kesepakatan" nilai-nilai objektif yang berlaku secara universal (al-khair), lintas budaya, sosial, politik kultural dan agama, bahkan lintas generasi dari masa ke masa. Sedangkan derivasinya bisa melahirkan aktualisasi yang berbeda 
dalam setiap komunitas masyarakat, namun tetap bertumpu pada "kebaikankebaikan universal-humanistik" (al-ma'rufaat), seperti: persaudaraan, kesalehan, cinta alam, dan lain-lain.

Adapun pluralisme sosiologis, masing-masing kelompok memiliki kebebasan faktual-sosiologis untuk menerjemahkan pandangan subjektif dan filosofis keagamaan atau keyakinan-kepercayaan (termasuk yang ateis sekalipun) masing-masing, tentang bagaimana menerjemahkannya ke dalam dunia faktual-sosial. Masing-masing umat beragama maupun yang ateis tentu harus mematuhi rambu-rambu kultural maupun yuridis formal dimana mereka berada. Memang akan banyak celah terjadinya konflik pada saat melakukan derivasi keyakinan masing-masing. Sejalan dengan perkembangan dunia IT yang membuat masyarakat menjadi lebih integrated, maka peran pakar IT, pakar hukum, pakar politik, pakar sosial dan pakar budaya menjadi lebih urgen untuk terus melakukan reformasi terhadap pijakan wilayah kepakaran masing-masing agar segenap komponen masyarakat lebih berhati-hati dan memiliki pinjakan yang jelas ketika akan saling bgerinteraksi satu sama lain. Bila terjadi juga benturan yang tak dapat dihindarkan - seperti adanya kasus penistaan agama - maka pegangan yuridis lah yang menjadi jalan keluar bersama, dimana mekanisme banding harus menjadi way out tanpa ada upaya intervensi serta tekanan dari pihak manapun.

Terlebih lagi kaitannya dengan figur mapun kelembagaan keagamaan haruslah dilakukan desakralisasi ketika ada kasus yang menyimpang dari masingmasing umat maupun kelembagaan keagamaan. Umat beragama dilarang bersikap "baper" ketika seorang figur atau lembaga atau partai keagamaan "terbukti" terlibat korupsi misalnya. Demikian pula kasus-kasus kekerasan dan sejenisnya. Dalam konteks inilah karya cerdas al-Makin menjadi sangat relevan.

Karya al-Makin sebenarnya bisa memperkaya pemahaman kultural sosial semua umat beragama, sebab al-Makin memperkenalkan, dalam banyak hal, membedah kekayaan kultural, filosofis, historis bahkan agama-agama besar dunia seperti: Islam, Kristen, Yahudi, Hindu, Budha dan lain-lain.

Menarik untuk dicermati bahwa dalam sejarah dinasti dan keagamaan juga terjadi proses inqusition (mihnah) yakni pada tahun 300 SM, terjadi perburuan terhadap orang-orang Kristen di Roma. Perburuan atau konflik keagaman disebabkan masing-masing umat menganut Pluralisme eksklusif yakni: "tiada kebenaran iman orang lain yang berada di luar agamanya sendiri". Hal sebaliknya juga terjadi yakni pada tahun 500 SM era Justinian, dimana Kristen di Roma mencapai puncaknya. Demikian pula halnya yang terjadi di 
Sasania era rezim Nushirwan, dimana Zoroaster menjadi satu-satunya iman, di luar Zoroaster tidak ada keimanan (h.121). Inilah bahaya yang melahirkan konflik sosial jika segolongan umat sudah terjebak pada prinsip truth claim.

Dalam kesejarahan umat Islam, fenomena pluralisme sebenarnya sudah biasa terjadi, khususnya era Islam klasik. Sebagai contoh, dalam soal membaca kitab suci al-Qur'an dengan logat yang saling berbeda (h.125). Walaupun pada era belakangan terjadi standarisasi bacaan dimana puncaknya terjadi di Mesir tahun 1924 (h.127). Pluralitas bacaan al-Qur'an, terjadi karena perbedaan latar belakang kesukuan, dimana masing-masing suku memiliki dialek (lahjah) yang berlainan. Bahkan juga bisa terjadi perbedaan dalam penafsiran, sesuai kreativitas ijtihad ulama masing-masing.

Kini usia al-Qur'an sekitar 1500 tahun yang telah dibaca milyaran umat Islam dengan beraneka ragam cita rasa, jenis mulut, dialek, lagu, cengkok dan model pemahaman atau penafsiran:"Tidak ada pemaknaan dan peresapan kalam Tuhan yang sama dalam waktu dan kesempatan yang berbeda, apalagi jika suatu generasi sudah terlampui" (h.128). Pluralitas bacaan al-Qur'an juga merambah ke bumi Nusantara melalui lidah muslim Jawa (orang Jawa sulit melafalkan 'ain, sering tertukar dengan ngain: nganngamta tidak 'an'amta), Minangkabau, Aceh, Sunda (yang sulit melafalkan huruf $f$, dan sering terbalik dengan huruf $p$ ), juga Madura (yang sulit membaca huruf $i$ secara lurus dan sering tertukar dengan huruf e: alladze tidakalladzi), dan seterusnya (h. 129).

Selain soal pluralitas keimanan dan cara membaca, juga memahami alQuran, al-Makin juga menuangkan idenya tentang terjadinya adu gagasan antara para teolog (mutakallimun) dan filosof, yang sampai hari ini dampaknya masih dirasakan umat Islam. Contohnya adalah, kritik teologis-filosofis Imam Ghazali yang Ash'ariyah terhadap para filosof aliran Mu'tazilah, atau juga dengan Ibnu Sina yang cenderung ke Syiah. Pasca Ibnu Sina, hadir Ibnu Rusyd (karya: Tahafut at-Tahafut) yang berbalik mengkritisi Imam Ghazali (Tahafut al-Falasifah) (h.196-204).

Pada era berikutnya debat metafisika antara filosof dan kaum teolog berkembang ke wilayah "empirisme Islam" sebagaimana yang diprakarsai para kaum Empirs Muslim seperti: Ibnu Taimiyah (terkenal dengan jargonnya: alhaqiqatu fi al-a'yan, la fi al-adzhan). Ada juga tokoh Ibnu Khaldun yang dikenal dengan proyek umran-nya atau peradaban, yakni tentang perkembangan masyarakat dari nomaden, menetap, membangun kekuasaan dalam dinasti, kapan kekuasaan itu bermula hingga menua seperti manusia, dan akhirnya mati. Ibnu Khaldun juga membahas tentang hubungan antar individu yang 
bekerjasama dalam sebuah organisasi. Khaldun juga menulis tentang pengaruh cuaca, geografi serta tentang naik turunnya sebuah peradaban. Studi kritis Ibnu Khaldun ini masih cukup relevan dalam kajian sosiologi, sejarah, antropologi bahkan biologi (h. 204-206).

Dari perdebatan teologis-filosofis ini umat Islam dewasa ini bisa belajar bagaimana cara berdebat secara Islami dengan saling menulis kitab, buku, jurnal di bidangnya masing-masing. Debat berdasarkan argumen, bukan berbasis sentimen pribadi (judgement). Umat juga perlu belajar dari sejarah Islam klasik bahwa seringkali perdebatan yang cerdas dan hangat, namun dihambat oleh rezim kekuasaan yang memihak pada salahsatu paham atau aliran keagamaan, sebagaimana yang pernah terjadi pada komunitas nonMuslim di Roma dan lain-lain. 